\title{
Inflence of clinical and genetic characteristics on ability to achive and maintain remission in JIA patients on etanercept treatment
}

\author{
Dragana S Lazarevic ${ }^{*}$, Jelena Vojinovic ${ }^{1}$, Gordana Susic ${ }^{2}$, Jelena Basic ${ }^{3}$ \\ From 21st European Pediatric Rheumatology (PReS) Congress \\ Belgrade, Serbia. 17-21 September 2014
}

\section{Introduction}

There are no official published recommendations how and when to stop treatment with biologics when remission achieved.

\section{Objectives}

Primary objective of this study was to evaluate influence of JIA subtype and duration of metotrexate (MTX) and steroids treatment on time to achieve and ability to maintain remission in JIA patients on biologic treatment. The second aim was to establish if there is contribution of tumor necrosis factor ó (TNFó-308) promoter and FokI vitamin D receptor (VDR) polymorphism on clinical outcome and possibility to discontinue treatment in JIA patients treated with biologics.

\section{Methods}

68 JIA patients treated with etanercept from Serbian biologic registry were included and retrospective data analysis performed. Genomic DNA was extracted from blood samples and TNFó-308 promoter and FokI VDR polymorphism was evaluated using the PCR-RFLP method. Disease subtypes, activity and treatment efficacy were collected during six years follow-up period in intervals after commencing etanercept: 6 months, 1 year and annually thereafter. Disease remission, as a condition to stop biologic treatment, was defined using Wallace and all criteria [1].

\section{Results}

At enrolment JIA patients mean age were $183.34 \pm 60$, 58 months, disease duration $70.29 \pm 44,57$ months, average dose of MTX $13.85 \pm 4.47 \mathrm{mg} / \mathrm{m} 2 /$ week. Etanercept treatment could be stopped after $42.66 \pm 21.64$ months with sustained remission during the next $30.33 \pm 21.04$ months. Therapy resistant patients required higher doses of MTX for a longer period, with statistically significance in systemic JIA $(15.97 \pm 3.56$ vs. $13.15 \pm 4.55, \mathrm{p}=0.016)$. Remission in this patients was shorter and they needed retreatment with biologics $(16.31 \pm 18.55$ vs. $35.80 \pm 19.53, \mathrm{p}=0.001)$ due to disease worsening. Treatment inefficacy was present in systemic JIA with the longest etanercept treatment 59.50 \pm 5.97 and shortest remission $17.67 \% \pm 9.82$, while etanercept therapy was the most effective in RF- JIA patients. There was no statistically significant difference in cumulative dose of steroids in different JIA subtypes. The distribution of TNFó-308 (GG, GA, AA) and FokI VDR genotypes (FF,Ff, ff) was not significantly different among JIA subtypes. After six years follow up period 37(54.5\%) patients were in remission (20 patients with $\mathrm{FF}+\mathrm{GA}$ and 17 patients with $\mathrm{Ff}+\mathrm{GA}$ polymorphism). Associate presence of $\mathrm{FF}+\mathrm{GA}$ genotype was present more frequently in patients who needed longer treatment and have had shorter remission time.

\section{Conclusion}

JIA patients needing higher MTX doses to control disease and have associated presence of GA+FF polymorphisms (for TNFó-308 promoter and FokI VDR, respectively) have less chances to achieve and sustain remission off biologics, especially in systemic JIA..

\section{Disclosure of interest}

None declared. 


\section{Authors' details}

'Pediatric Rheumatology, Clinic of Pediatrics, Clinical Center Nis, Nis, Serbia.

${ }^{2}$ Pediatric Rheumatology, Institute of Rheumatology, Belgrade, Serbia.

${ }^{3}$ Institute of Biochemistry, Faculty of medicine, Nis, Serbia.

Published: 17 September 2014

\section{Reference}

1. Wallace, et al: Preliminary criteria for clinical remission for select categories of juvenile idiopathic arthritis. J Rheumatol 2004, 31:2290-2294.

doi:10.1186/1546-0096-12-S1-P48

Cite this article as: Lazarevic et al:: Inflence of clinical and genetic characteristics on ability to achive and maintain remission in JIA patients on etanercept treatment. Pediatric Rheumatology 2014

12(Suppl 1):P48,

Submit your next manuscript to BioMed Central and take full advantage of:

- Convenient online submission

- Thorough peer review

- No space constraints or color figure charges

- Immediate publication on acceptance

- Inclusion in PubMed, CAS, Scopus and Google Scholar

- Research which is freely available for redistribution

Submit your manuscript at www.biomedcentral.com/submit
Ciomed Central 